\title{
Water Quality and Monitoring of Some Pollution Indicators in Lake Manzala, Egypt
}

\author{
Mokhtar S. Beheary ${ }^{1}$, Eman M. Saleh ${ }^{2}$, Mamdouh S. Serag ${ }^{3}$ \\ ${ }^{1}$ Environmental Science Department, Faculty of Sciences, Port Said University, Egypt \\ ${ }^{2}$ B. SC in Environmental Sciences, Environmental Sciences Department, Faculty of Sciences, Damietta University \\ ${ }^{3}$ Prof. of Plant Ecology Botany Department, Faculty of Science Damietta University
}

Correspondence Author: Mokhtar S. El-Beheary, Environmental Science Department, Faculty of Sciences, Port Said University, Egypt

E-mail: beheary@hotmail.com

Received date: 28 August 2019, Accepted date: 2 December 2019, Online date: 20 December 2019

Copyright: (C) 2019 Mokhtar S. El-Beheary et al., This is an open-access article distributed under the terms of the Creative Commons Attribution License, which permits unrestricted use, distribution, and reproduction in any medium, provided the original author and source are credited.

\begin{abstract}
Lake Manzala is one of the most important fishing sources in Egypt. It faces many environmental challenges that affect its quality. Due to excessive discharge of wastewater, the quality of water and fish production deteriorated. This study was carried out in nine different sites in the eastern and southern parts of Lake Manzala in two Governorates; Port Said (six sites) and Dakahliya (three sites) in North Delta, Egypt. Water samples were collected seasonally in 19 May 2017, 19 August 2017, 12 November 2017, and in 7 January 2018 (spring, summer, autumn, and winter). Samples were collected by a boat from the lake. Temperature, latitude, longitude, and $\mathrm{pH}$ were determined in the field. Global Position System (Garmin GPS) detected the Latitude and longitude for sampling sites within Lake Manzala for each site. Statistical analysis of the results were performed and was expressed by mean SE. The aim of this study is to monitor some quality indicators for lake water. The results showed significant changes in water characteristics including: temperature $\left(14.3^{\circ} \mathrm{C}-35.5^{\circ} \mathrm{C}\right), \mathrm{pH}(7.68-9)$, turbidity $(0.4 \mathrm{mg} / \mathrm{l}$ - $321 \mathrm{mg} / \mathrm{l})$, total hardness $(176.41 \mathrm{mg} / \mathrm{l}$ - $3140 \mathrm{mg} / \mathrm{l})$, total solids $(1548.8 \mathrm{mg} / \mathrm{l}$ - 19379.2 $\mathrm{mg} / \mathrm{l})$, chlorides $(468.65 \mathrm{mg} / \mathrm{l}$ $11621.28 \mathrm{mg} / \mathrm{l})$, sodium $(321.06 \mathrm{mg} / \mathrm{l}-7585.21 \mathrm{mg} / \mathrm{l})$, total nitrogen $(0.148 \mathrm{mg} / \mathrm{l}-10.09 \mathrm{mg} / \mathrm{l})$, total phosphorus $(0.15 \mathrm{mg} / \mathrm{l}-0.96$ $\mathrm{mg} / \mathrm{l})$, Dissolved oxygen(0.7 mg O2/l -12.4 mg O2V), biological oxygen demand(6.8 mg O2/l - 9.6 mg O2V), Chemical oxygen

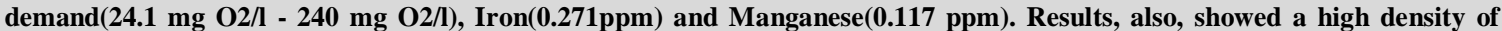
faecal coliform count and total viable bacterial count. The results show deterioration in the quality of the lake water, so the state should pay attention to this problem because it negatively affects the production of lake fish in addition to other negative consequences.
\end{abstract}

Keywords: Lake Manzala, Nine sites, Seasonally, Quality indicators, Statistical analysis.

\section{INTRODUCTION}

A large group of pollutants has caused pollution for the marine environment and this has been brought to the attention of the world over the past few decades. The main sources of pollution are agricultural, industrial, and human activities. Due to the rapid industrial expansion, large quantities of industrial wastes are discharged into the lakes. This can change the characteristics of the aquatic environment and accumulate heavy metals until they reach toxic levels [1,2].

The Mediterranean coastline in Egypt has five brackish lakes. These lakes are, from east to west, Bardawil, Manzala, Burullus, Edku, and Mariut. These lakes connect directly with the Mediterranean Sea except Lake Mariut. The present thesis throws light on the most critical Egyptian Delta Lakes. Manzala Lake is considered the most important sources of fish in Egypt, where the lake's production of fish is about 36-50\% of the total annual output of Egyptian lake [3, 4].

Lake Manzala lies on the northeastern boundary of the Nile Delta. The lake lies between $31^{\circ} 45^{\prime}, 32^{\circ} 15^{\prime} \mathrm{E}$ and $31^{\circ} 00^{\prime}, 31^{\circ} 35^{\prime} \mathrm{N}$. while the Mediterranean Sea has bordered it from the northern part. The Suez Canal is bordered the lake from the eastern part, Port Said and Ismailia governorates. Al-Sharqiya governorate is bounded the lake from the north, and Dakahliya governorate is bounded from the southwestern region. Damietta governorate has bordered the lake from the western part [5].

It connects with water from three boundaries from the west, north and east parts. It receives a small discharge of freshwater through the Enanya Canal, which links the lake to Damietta Branch, of the River Nile, from the west. The north-west side of the lake connects to the Damietta branch of the Nile River through Al-Sofraa and Al-Ratma channels in the Northern of Damietta. While the eastern part of the lake is connected to Suez Canal with a very narrow canal (El-Qabuty Canal). This part provides the 
lake with saline water. The northern boundary of the lake is the Mediterranean Sea, which discharges also saline water into the lake. There are several connections (outlets) between it and the lake, which consists of a narrow sandy margin. The lake connects to the Mediterranean Sea by a narrow sandy margin: El-Baghdadi, New Damietta, Al-Gamil, and the new Gamil Bougesses. These outlets improve the water quality status of the lake; the main outlets are El-Gamil and the New El-Gamil outlets. [6, 7].

Manzala receives agricultural, industrial, and domestic wastes through many drains such as Ramses, Matariya, Faraskur, ElSerw, Hadous, and Bahr El-Baqar [8] (Fig. 1). Bahr el Baqar drain is considered the most dangerous source of pollution. It has become a distributor of diseases and epidemics to citizens. While the agricultural drainage in the past was a new addition of water to the lake and allowing for fish growth well, but now it has become like a dangerous source of pesticides, fertilizers, and organic materials, which have a definite impact on the aquatic environment and reflected on the human and public health [9].



Fig. 1: Image, A; showing the location of Lake Manzala in Egypt. Image, B; showing the map of Manzala Lake and the five drains (Source [10])

\section{MATERIALS AND METHODS}

This study was carried out in nine different sites in the eastern and southern parts of Lake Manzala in two Governorates; Port Said (six sites) and Dakahliya (three locations) (Fig. 2). Water samples were collected seasonally on 19 May 2017 , 19 August 2017, 12 November 2017, and on 7 January 2018 (spring, summer, autumn, and winter). Temperature, latitude, longitude, and $\mathrm{pH}$ were determined in the field. Global Position System (Garmin GPS) detected the Latitude and longitude for sampling sites within Lake Manzala for each site (Table. 1). Conservation methods were restricted to $\mathrm{pH}$ control, chemical addition or/and refrigeration [11].

All statistical analyses were performed by a statistical software package (SPSS 15.0 for Microsoft Windows, SPSS Inc.). Descriptive results were expressed as mean SE. Differences in continuous variables were assessed using ANOVA test. All tests were two-tailed and statistical significance evaluated at the 0.05 level. 
Fig. 2: Showing locations of samples in Lake Manzala

Table 1: The coordinates for the different sites of the study area.

\begin{tabular}{|c|c|c|c|c|}
\hline Site No. & Name of site & Governorate & Latitude (N) & Longitude (E ) \\
\hline I & Matariya Research Institution (A) & Dakahliya & $\mathrm{N} 31^{\circ} 11^{\prime} 38.0616^{\prime \prime}$ & E $32^{\circ} 2^{\prime} 19.4352^{\prime \prime}$ \\
\hline II & Port-Said Canal (B) & Port-Said & $\mathrm{N} \mathrm{31^{ \circ } 1 1 ^ { \prime } 9 . 6 ^ { \prime \prime }}$ & E $32^{\circ} 9^{\prime} 7.9272^{\prime \prime}$ \\
\hline III & Bahr Al-Baqar (C) & Port-Said & N 31 $10^{\prime} 2.4744^{\prime \prime}$ & E $32^{\circ} 11^{\prime} 58.722^{\prime \prime}$ \\
\hline IV & Al-Gamil Al-Dakhly (D) & Port-Said & N 31ํ 13' 33.744" & E $32^{\circ} 13^{\prime} 49.2456^{\prime \prime}$ \\
\hline $\mathrm{V}$ & Ashtom El Gamil National Park (E) & Port-Said & $\mathrm{N} \mathrm{31}{ }^{\circ} 14^{\prime} 43.2312^{\prime \prime}$ & E $32^{\circ} 12^{\prime} 40.9392^{\prime \prime}$ \\
\hline VI & Um El-Jeef (F) & Port-Said & N 31ํ1'ㄱ․0280" & E $32^{\circ} 10^{\prime} 31.1520^{\prime \prime}$ \\
\hline VII & Al-Najailh (G) & Port-Said & N $31^{\circ} 13^{\prime} 14.6352^{\prime \prime}$ & E $32^{\circ} 7^{\prime} 23.2968^{\prime \prime}$ \\
\hline VIII & Al-Nasaimh (H) & Dakahliya & $\mathrm{N} \mathrm{31^{ \circ } 1 3 ^ { \prime } 5 1 . 9 3 4 8 ^ { \prime \prime }}$ & E $32^{\circ} 0^{\prime} 46.9008^{\prime \prime}$ \\
\hline IX & Al-lisah (I) & Dakahliya & N $31^{\circ} 14^{\prime} 10.2984^{\prime \prime}$ & E $31^{\circ} 52^{\prime} 8.9976^{\prime \prime}$ \\
\hline
\end{tabular}

\section{RESULTS AND DISCUSSION}

\section{Physico-chemical quality criteria \\ 1.1 Temperature}

The minimum mean value of water temperature was $\left(15.3 \pm 0.9^{\circ} \mathrm{C}\right)$ recorded during January when the temperature range between 14.3 and $17^{\circ} \mathrm{C}$. The maximum mean value of water temperature was $\left(33.7 \pm 0.9^{\circ} \mathrm{C}\right)$ recorded during summer when temperature range between 32.5 and $35.5^{\circ} \mathrm{C}$. This agrees with El-Refaie (2010) [12]. There were statistically significant differences (P $<0.0001$ ) in the mean seasonal surface water temperature in Lake Manzala. (Table. 2) shows these results.

In (Table. 5) There is a significant positive correlation between Temperature and Turbidity, Hardness, Iron and Manganese $(\mathrm{r}=$ $0.617,0.672,0.869,0.588$ and 0.586 , respectively). There is a significant negative correlation between Temperature and Nitrogen and Dissolved Oxygen $(r=-0.648$ and -0.561 , respectively). There is also a significant negative correlation between $\mathrm{pH}$ and Sodium and Phosphorus $(\mathrm{r}=-0.801$ and -0.658 , respectively).

\subsection{Hydrogen ion concentration $(\mathrm{pH})$}

The minimum mean value of water $\mathrm{pH}$ was $(8.04 \pm 0.3)$ recorded during January (winter) when water $\mathrm{pH}$ ranged from $7.68-$ 8.44. The maximum mean value of water $\mathrm{pH}$ was $(8.44 \pm 0.1)$ recorded during spring ranging between $7.9-9$. These results are agreed with Fathi et al., 2003 and Ahmed et al., 2013) [13, 14]. There were no statistically significant differences (P=0.0714) in the mean seasonal surface water $\mathrm{pH}$ in Lake Manzala. (Table. 2) represents these results.

In (Table. 5) There is a significant negative correlation between $\mathrm{pH}$ and Sodium and Phosphorus $(\mathrm{r}=-0.801$ and -0.658 , respectively). 


\subsection{Turbidity}

In (Table. 2) Turbidity recorded a minimum value in winter and maximum in summer which value was $23.7 \pm 34.7 \mathrm{mg} / \mathrm{l}$, this is in agreement with Ali et al., (2005) [15]. There were statistically significant differences $(\mathrm{P}=0.002)$ in the mean seasonal surface water turbidity in Lake Manzala.

In (Table. 5) There is a significant positive correlation between Turbidity and Hardness, Iron and Manganese $(\mathrm{r}=0.630,0.689$ and 0.774 , respectively).

\subsection{Total Hardness}

The maximum mean value of water hardness was $(1117 \pm 318 \mathrm{ppm})$ recorded during spring ranging between 495.0 and 3140 ppm. The minimum mean value of hardness was $(328.3 \pm 122 \mathrm{ppm})$ recorded during January (winter). At all stations sampled, the highest value of water hardness was recorded at Ashtom El Gamil National Park station during winter (3140 ppm), and this may be due to saltwater. The present results agree with Khalil (1990) and Zyada (1995) [16, 17]. There were no statistically significant differences $(\mathrm{P}=0.065)$ in the mean seasonal for the water hardness in Lake Manzala. (Table. 2) represents these results.

In (Table. 5) There is a significant positive correlation between Hardness and Total solids, Chloride and Biological Oxygen Demand $(\mathrm{r}=0.811,0.726$ and 0.775 , respectively).

\subsection{Total solids (TS)}

The highest mean value for total solids was recorded during the spring season $5469 \pm 2089 \mathrm{mg} / \mathrm{l}$ and the lowest mean value for total solids was recorded during the autumn season $3998 \pm 1190 \mathrm{mg} / \mathrm{l}$. At all sites sampled, total solids are obviously increased toward the north, the maximum value was $19379.2 \mathrm{mg} / \mathrm{l}$ at Ashtom El Gamil National Park station during the winter. This may be due to the effect of saltwater, which is supplied from the Mediterranean to this site. This observation is consistent with Khalil (1990); El-Enany (2004); and El-Kafrawy (2004) [16, 18, 19]. There were statistically significant differences $(\mathrm{P}<0.0001)$ in the mean seasonal total solids in Lake Manzala. (Table. 2) represents these results.

In (Table. 5) There is a significant positive correlation between Total solids and Chloride, Sodium, Biological Oxygen Demand and Chemical Oxygen Demand $(\mathrm{r}=0.910,0.723,0.822$ and 0.522 , respectively).

\subsection{Dissolved Oxygen (DO)}

The maximum mean value of Dissolved oxygen (DO) was observed during winter is $9.3 \pm 0.9 \mathrm{mg} \mathrm{O}_{2} / 1$, while the minimum value was recorded during summer is $2.4 \pm 0.3 \mathrm{mg} \mathrm{O} / \mathrm{l}$. In all sites, the minimum value of Dissolved oxygen was $0.7 \mathrm{mg} \mathrm{O}_{2} / 1 \mathrm{in}$ the water collected from Bahr Al-Baqar site during the winter season; this may be because of a huge amount of organic and inorganic pollutants discharged into Bahr Al-Baqar station which consumes in nitrification, oxidation and decomposition processes. The maximum value was $12.4 \mathrm{mg} \mathrm{O}_{2} / 1$ at Ashtom El Gamil National Park during winter, this may be due to a low water temperature which causes the solubility of oxygen. Results are similar to those obtained by El-Enany(2004); Abdel-Satar and Geneid (2009) [18, 20]. There were statistically significant differences $(\mathrm{P}<0.0001)$ in the mean seasonal surface water dissolved oxygen concentration in Lake Manzala. (Table. 2) represents these results.

In (Table. 5) There is a significant positive correlation between Dissolved Oxygen and Chemical Oxygen Demand $(\mathrm{r}=0.525)$. There is a significant negative correlation between Dissolved Oxygen and Faecal Coliform Count $(\mathrm{r}=-0.558)$.

\subsection{Biological Oxygen Demand (BOD)}

The maximum mean value of Biological oxygen demand (BOD) was observed during spring was $8.5 \pm 0.2 \mathrm{mg} \mathrm{O}_{2} / \mathrm{l}$, while the minimum mean value was recorded during winter was $7.8 \pm 0.2 \mathrm{mg} \mathrm{O}_{2} / \mathrm{l}$. The mean value of Biological oxygen demand is $8.2 \mathrm{mg}$ $\mathrm{O}_{2} / \mathrm{l}$ and these results agree with El-Alfy (2011) [21], (9.2 $\left.\mathrm{mg} \mathrm{O} / \mathrm{l}\right)$. There were no statistically significant differences $(\mathrm{P}=0.1107)$ in the mean seasonal surface water turbidity in Lake Manzala. (Table. 2) shows these results.

In (Table. 5) There is a significant positive correlation between Biological Oxygen Demand and Faecal Coliform Count ( $P$ value $=0.804)$.

\subsection{Chemical Oxygen Demand (COD)}

The maximum mean value of Chemical oxygen demand (COD) was observed during winter is $132.5 \pm 19.5 \mathrm{mg} \mathrm{O}_{2} / 1$, while the minimum mean value was recorded during autumn is $54.7 \pm 6.6 \mathrm{mg} \mathrm{O}_{2} / 1$. In all sites, the maximum value was $240.1 \mathrm{mg} \mathrm{O}_{2} / 1$ at Ashtom El Gamil National Park during the winter, and this may be due to this site is near to the industrial area at Port-Said City, While the minimum value of chemical oxygen demand was $24.1 \mathrm{mg} \mathrm{O}_{2} / 1$ in the water collected from Matariya Research Institution site during the spring season. This may be due to this site away from factories. .This finding is consistent with AlAlfy (2011) [21]. There were statistically significant differences $(\mathrm{P}=0.0074)$ in the mean seasonal surface water Chemical Oxygen Demand in Lake Manzala. (Table. 2) represents these results.

In (Table. 5) There is a significant positive correlation between Chemical Oxygen Demand and Total Viable Bacterial Count $(P$ value $=0.802$ ).

Table 2: Mean and range of Physico-chemical parameters from the sampling sites of Manzala Lake at different seasons

\begin{tabular}{|c|c|c|c|c|c|}
\hline \multicolumn{7}{|c|}{ Parameters } & Winter & Spring & Summer & Autumn & P-value \\
\hline Mean & $15.3 \pm 0.3$ & $24.8 \pm 0.4$ & $33.7 \pm 0.3$ & $24.6 \pm 0.4$ & \multirow{2}{*}{$<0.0001$} \\
\hline Range & $14.3-17.0$ & $23.0-27.0$ & $32.5-35.5$ & $23.4-26.8$ & \\
\hline
\end{tabular}


Citation: Mokhtar S. El-Beheary et al., 2019. Water Quality and Monitoring of Some Pollution Indicators in Lake Manzala, Egypt. Advances in Environmental Biology., 13(12): 21-29. DOI:10.22587/aeb.2019.13.12.5

\begin{tabular}{|c|c|c|c|c|c|}
\hline \multicolumn{6}{|c|}{ pH values } \\
\hline Mean & $8.0 \pm 0.1$ & $8.4 \pm 0.1$ & $8.4 \pm 0.1$ & $8.2 \pm 0.1$ & \multirow{2}{*}{0.0714} \\
\hline Range & $7.7-8.4$ & $7.9-9.0$ & $7.8-8.9$ & $7.7-8.7$ & \\
\hline \multicolumn{6}{|c|}{ Turbidity (mg/l) } \\
\hline Mean & $12.02 \pm 4.4$ & $34.4 \pm 4.8$ & $123.7 \pm 34.7$ & $106 \pm 25.8$ & \multirow{2}{*}{0.002} \\
\hline Range & $0.4-37.4$ & $5.0-47.2$ & $24.0-321.0$ & $16.9-245.2$ & \\
\hline \multicolumn{6}{|c|}{ Hardness (ppm) } \\
\hline Mean & $328.3 \pm 122$ & $1117 \pm 318$ & $922.2 \pm 159$ & $650.8 \pm 118$ & \multirow{2}{*}{0.065} \\
\hline Range & $176.4-1275$ & $495.0-3140$ & $501.0-2010$ & $329.7-1260$ & \\
\hline \multicolumn{6}{|c|}{ Total solids (TS) } \\
\hline Mean & $4736 \pm 1971$ & $5469 \pm 2089$ & $3720 \pm 810.3$ & $3998 \pm 1190$ & \multirow{2}{*}{$<0.0001$} \\
\hline Range & 1549-19379 & $1651-19900$ & $1613-9062$ & $1578-12560$ & \\
\hline \multicolumn{6}{|c|}{ Dissolved oxygen $\left(\mathrm{mg} \mathrm{O}_{2} / \mathrm{l}\right)$} \\
\hline Mean & $9.3 \pm 0.9$ & $7.4 \pm 0.6$ & $2.4 \pm 0.3$ & $6.8 \pm 0.9$ & \multirow{2}{*}{$<0.0001$} \\
\hline Range & $3.4-12.4$ & $4.9-9.8$ & $0.7-3.4$ & $2.8-11.7$ & \\
\hline \multicolumn{6}{|c|}{ Biological oxygen demand $\left(\mathrm{mg} \mathrm{O}_{2} / \mathrm{l}\right)$} \\
\hline Mean & $7.8 \pm 0.2$ & $8.5 \pm 0.2$ & $7.8 \pm 0.2$ & $8.2 \pm 0.2$ & \multirow{2}{*}{0.1107} \\
\hline Range & $7.0-8.5$ & $7.4-9.6$ & $7.1-8.7$ & $6.8-8.9$ & \\
\hline \multicolumn{6}{|c|}{ Chemical oxygen demand (mg $\left.\mathrm{O}_{2} / \mathrm{l}\right)$} \\
\hline Mean & $132.5 \pm 19.5$ & $71.3 \pm 19.1$ & $94.0 \pm 12.7$ & $54.7 \pm 6.6$ & \multirow{2}{*}{0.0074} \\
\hline Range & $80.2-240.1$ & $24.1-168.9$ & $50.4-153.8$ & 30.5 .95 .0 & \\
\hline
\end{tabular}

Data expressed as mean $\pm \mathrm{SE}, P$-value $<0.05$ is considered statistically significant.

\subsection{Chloride}

In (Table. 3), the maximum mean value of Chlorides was observed during autumn is $2653 \pm 1283 \mathrm{mg} / \mathrm{l}$, while the minimum value was recorded during spring is $1545 \pm 405 \mathrm{mg} / \mathrm{l}$. In all sites, the concentration of chloride value obviously increases toward the north. The results agree with those obtained by Ali (2008) and Abdul Sattar and Geneid (2009) [22, 20]. There were no statistically significant differences $(\mathrm{P}=0.8451)$ in the mean seasonal surface water chloride in Lake Manzala.

In (Table. 5) There is a significant positive correlation between Chloride and Sodium, Biological Oxygen Demand and Chemical Oxygen Demand ( $\mathrm{r}=0.615,0.692$ and 0.518 , respectively).

\subsection{Sodium}

In (Table. 3), The minimum mean value of water sodium concentration was $(966.3 \pm 208.4 \mathrm{mg} / \mathrm{l})$ recorded during summer. The maximum mean value of water sodium concentration was $(2041 \pm 829.2 \mathrm{mg} / \mathrm{l})$ recorded during winter. Similar observations are consistent with those obtained by El-Kafrawy (2004), Ali (2008) and Abdel-Satar and Geneid (2009) [19, 22, 20].There were no statistically significant differences $(\mathrm{P}=0.6205)$ in the mean seasonal sodium in Lake Manzala.

In (Table. 5) There is a significant positive correlation between Sodium and Biological Oxygen Demand and Chemical Oxygen Demand ( $\mathrm{r}=0.584$ and 0.527 , respectively).

\subsection{Nitrogen $(\mathbf{N})$}

In (Table. 3), the maximum mean value of nitrogen was observed during winter is $6.4 \pm 0.9 \mathrm{mg} / \mathrm{l}$, while the minimum mean value was recorded during summer is $1.9 \pm 0.6 \mathrm{mg} / \mathrm{l}$. The maximum value was $10.09 \mathrm{mg} / \mathrm{l}$ in Bahr Al-Baqar during winter. This may be due to the agricultural wastes discharged into the drainage. This agrees with Ali (2008) and Abdel-Satar and Geneid (2009) [22, 20]. There were statistically significant differences $(\mathrm{P}=0.0010)$ in the mean seasonal for nitrogen value in Lake Manzala.

In (Table. 5) There is a significant positive correlation between Nitrogen and phosphorus, Iron, Manganese and Total Viable Bacterial Count $(\mathrm{r}=0.873)(P$ value $=0.707,0.941$ and 0.578$)$

\subsection{Total phosphorus}

In (Table. 3), The minimum mean value of water total phosphorus concentration was $(0.3988 \pm 0.1 \mathrm{mg} / \mathrm{l}) \mathrm{recorded} \mathrm{during}$ autumn. The maximum mean value of water total phosphorus concentration was $(0.64 \pm 0.1 \mathrm{mg} / \mathrm{l})$ recorded during winter. Similar observations are consistent with those obtained by Khalil (1990); Zyadah (1995); El-Enany (2004); Ali (2008) [16, 17, $18,22]$. At all stations sampled, the highest value of water total phosphorus concentration was recorded at Bahr Al-Baqar station during winter $(0.96 \mathrm{mg} / \mathrm{l})$. This may be because of highly contaminated sewage and agricultural waste which discharged into the drainage (Ali, 2008) [23]. There were statistically significant differences $(\mathrm{P}=0.0007)$ in the mean seasonal surface water nitrogen in Lake Manzala.

In (Table. 5) There is a significant positive correlation between phosphorus and Iron, Dissolved Oxygen and Biological Oxygen Demand $(P$-value $=0.867,0.906$ and 0.648$)$

\section{The concentration of heavy metals in Manzala Lake}

\subsection{Iron concentration}

In (Table. 3), the maximum mean value of iron was $(0.8 \pm 0.2 \mathrm{mg} / \mathrm{l})$ recorded during summer. The results showed a slight increase in iron concentrations during autumn and summer compared to other seasons due to high temperature, which reduces the rate of Fe absorption of aquatic organisms. Similar observations are consistent with those obtained by Berg et al. (1995) [23]. There were statistically significant differences $(\mathrm{P}=0.0032)$ in the mean seasonal surface water iron concentration in Lake Manzala. 
Citation: Mokhtar S. El-Beheary et al., 2019. Water Quality and Monitoring of Some Pollution Indicators in Lake Manzala, Egypt. Advances in Environmental Biology., 13(12): 21-29. DOI:10.22587/aeb.2019.13.12.5

In (Table. 5) There is a significant positive correlation between Iron and Manganese, Faecal Coliform Count and Total Viable Bacterial Count $(r=0.784,0.766$ and 0.597 , respectively). Whereas, there is a significant negative correlation between Iron and Dissolved Oxygen $(r=-0.796)$.

\subsection{Manganese concentration}

In (Table. 3), the highest mean value for manganese concentration was recorded during summer $0.2 \pm 0.04 \mathrm{mg} / \mathrm{l}$, and the lowest mean value for manganese concentration was recorded during the winter season $0.04 \pm 0.01 \mathrm{mg} / \mathrm{l}$. At all sites sampled, the maximum cost was $0.403 \mathrm{mg} / \mathrm{l}$ at Bahr Al-Baqar station during the summer. This may be due to agricultural discharge that contains fertilizers, which are discharged into Bahr Al-Baqar drainage. Moreover, fish farms near the site use the remains of chicken farms, which rich in manganese, as food for fish. These results are in agreement with Ibrahim et al. (1999) [24]. There were statistically significant differences $(\mathrm{P}<0.0001)$ in the mean seasonal surface water manganese concentration in Lake Manzala.

In (Table. 5) There is a significant positive correlation between Manganese and Faecal Coliform Count and Total Viable Bacterial Count $(\mathrm{r}=0.652$ and 0.590 , respectively). Whereas, there is a significant negative correlation between Manganese and Dissolved Oxygen $(r=-0.650)$.

Table 3: Mean and range of main ions and heavy metals measured in the sampling sites of Manzala Lake at different seasons

\begin{tabular}{|c|c|c|c|c|c|}
\hline Parameters & Winter & Spring & Summer & Autumn & $P$ value \\
\hline \multicolumn{6}{|c|}{ Chloride (mg/l) } \\
\hline Mean & $2106 \pm 767$ & $1545 \pm 405$ & $2183 \pm 854$ & $2653 \pm 1283$ & \multirow{2}{*}{0.8451} \\
\hline Range & $540.3-7056$ & $468.7-4311$ & $507.6-7522$ & $627.9-11621$ & \\
\hline \multicolumn{6}{|c|}{ Sodium (mg/l) } \\
\hline Mean & $2041 \pm 829.2$ & $1607 \pm 600.6$ & $966.3 \pm 208.4$ & $1584 \pm 463.2$ & \multirow{2}{*}{0.6205} \\
\hline Range & $621.2-7585$ & $353-5498$ & $321.1-2325$ & $456.5-5473$ & \\
\hline \multicolumn{6}{|c|}{ Nitrogen (mg/l) } \\
\hline Mean & $6.4 \pm 0.9$ & $3.5 \pm 0.7$ & $1.9 \pm 0.6$ & $4.3 \pm 0.7$ & \multirow{2}{*}{0.0010} \\
\hline Range & $3.3-10.1$ & $1.8-7.5$ & $0.2-4.8$ & $2.1-7.4$ & \\
\hline \multicolumn{6}{|c|}{ phosphate (mg/l) } \\
\hline Mean & $0.64 \pm 0.1$ & $0.49 \pm 0.1$ & $0.40 \pm 0.1$ & $0.3988 \pm 0.1$ & \multirow{2}{*}{0.0713} \\
\hline Range & $0.1-1.0$ & $0.3-0.7$ & $0 . .2-0.7$ & $0.3-0.8$ & \\
\hline \multicolumn{6}{|c|}{ Iron (mg/l) } \\
\hline Mean & $0.02 \pm 0.01$ & $0.06 \pm 0.01$ & $0.8 \pm 0.2$ & $0.3 \pm 0.1$ & \multirow{2}{*}{0.00032} \\
\hline Range & 0.004-0.09 & $0.01-0.12$ & $0.12-2.21$ & $0.03-0.99$ & \\
\hline \multicolumn{6}{|c|}{ Manganese (mg/l) } \\
\hline Mean & $0.04 \pm 0.01$ & $0.05 \pm 0.01$ & $0.2 \pm 0.04$ & $0.14 \pm 0.03$ & \multirow{2}{*}{$<0.0001$} \\
\hline Range & $0.0-0.09$ & $0.0-0.09$ & $0.02-0.4$ & $0.01-0.23$ & \\
\hline
\end{tabular}

Data expressed as mean $\pm \mathrm{SE}, P$-value $<0.05$ is considered statistically significant

\section{Biological quality standards for the lake water \\ 3.1 Faecal Coliform Count}

In (Table. 4), the highest mean value for Faecal coliform count was recorded during the summer season $46.6 \pm 7.9 \mathrm{cfu} \times 10^{3} / \mathrm{ml}$ and the lowest mean value for the faecal coliform count was recorded during the spring season $2.2 \pm 0.8 \mathrm{cfu} \times 10^{3} / \mathrm{ml}$. The High levels of the faecal coliform count were observed in summer, autumn, winter than spring mainly from agricultural drainage; this may be attributed to human sewage pollution in concurrent with the gradual increase in water temperature during these seasons. These results are agreed with by Gad (2005); Giannoulis et al. (2005); Younis and Nafea (2012) [25, 26, 27]. There were statistically significant differences $(\mathrm{P}<0.0001)$ in the mean seasonal surface water fecal coliform count in Lake Manzala.

In (Table. 5) There is a significant positive correlation between Faecal Coliform Count and Total Viable Bacterial Count ( $\mathrm{r}$ $=0.761)$.

\subsection{Total Viable Bacterial Count}

In (Table. 4), the maximum mean value of total viable bacterial count was observed during summer is $37.3 \pm 4.2 \mathrm{cfu} \times 10^{3} / \mathrm{ml}$, while the minimum mean value was recorded during spring is $3.6 \pm 0.5 \mathrm{cfu} \times 10^{3} / \mathrm{ml}$. In all sites where samples, the maximum value was $63.6 \mathrm{cfu} \times 10^{3} / \mathrm{ml}$ at Bahr Al-Baqar during the summer, this may be due to the huge amount of agricultural drainage and municipal wastes which discharge from Bahar Al-Baqar drainage into the lake. These results are agreed with by Fernandes et al. (1999) and Al-Harbi (2003) [28, 29]. They found the bacteria load in water samples increased by increasing the temperature of water and organic matter. There were statistically significant differences $(\mathrm{P}<0.0001)$ in the mean seasonal surface water nitrogen in Lake Manzala.

Table 4: Mean and range of Biological prama measured in the sampling sites of Manzala Lake at different seasons

\begin{tabular}{|c|c|c|c|c|c|}
\hline Parameters & Winter & Spring & Summer & Autumn & $P$ value \\
\hline Mean & $10.1 \pm 2.3$ & $2.2 \pm 0.8$ & $46.6 \pm 7.9$ & $33.5 \pm 2.9$ & \multirow{2}{*}{ Faecal coliform count $(\mathbf{c f u} \times \mathbf{1 0}$ ) } \\
\hline Range & $1.15-19.9$ & $0.10-7.7$ & $20.0-97.0$ & $21.3-50.2$ & \\
\hline
\end{tabular}


Citation: Mokhtar S. El-Beheary et al., 2019. Water Quality and Monitoring of Some Pollution Indicators in Lake Manzala, Egypt. Advances in Environmental Biology., 13(12): 21-29. DOI:10.22587/aeb.2019.13.12.5

\begin{tabular}{|l|c|c|c|c|c|}
\hline \multicolumn{7}{|c|}{ Total Bacterial count $\left(\mathbf{c f u} \times \mathbf{1 0}^{\mathbf{3}}\right) / \mathbf{m l}$} \\
\cline { 1 - 4 } Mean & $19.5 \pm 4.1$ & $3.6 \pm 0.5$ & $37.3 \pm 4.2$ & $36.5 \pm 2.4$ & \multirow{2}{*}{$<0.0001$} \\
\hline Range & $8.0-39.0$ & $0.43-5.6$ & $20.0-63.6$ & $69.0-52.0$ & \\
\hline
\end{tabular}

Data expressed as mean $\pm \mathrm{SE}, P$-value $<0.05$ is considered statistically significant

\section{CONCLUSION}

Water samples were collected seasonally from nine different sites from the southern and eastern part of the lake. This study sheds light on the monitoring of the water quality in the lake because of its economic importance and an important source of fish production. Therefore, the study showed the effect of discharge of agricultural and industrial wastes on some physical, chemical, and biological properties of water. The obtained results are useful in management the lake particular with water pollution, nitrification, and heavy metals.

Table 5: Pearson bivariate correlation co-efficient of water quality parameters in the sampling sites of Manzala Lake at different seasons during (2017 and 2018)

\begin{tabular}{|c|c|c|c|c|c|c|c|c|c|c|c|c|c|c|c|c|c|}
\hline \multicolumn{2}{|c|}{ Parameters } & \multirow[t]{3}{*}{$\mathbf{T}$} & \multirow{2}{*}{\begin{tabular}{|c|}
$\mathbf{p H}$ \\
0.499 \\
\end{tabular}} & \multirow{2}{*}{$\begin{array}{c}\text { Turbidit } \\
\mathbf{y}\end{array}$} & \multirow{2}{*}{$\begin{array}{c}\text { Hardnes } \\
\mathbf{s}\end{array}$} & \multirow{2}{*}{\begin{tabular}{|c|} 
TS \\
0.320 \\
\end{tabular}} & \multirow{2}{*}{\begin{tabular}{|c|}
$\mathbf{C L}$ \\
0.259
\end{tabular}} & \multirow{2}{*}{$\begin{array}{c}\mathbf{N a} \\
0.029\end{array}$} & \multirow{2}{*}{\begin{tabular}{|c|}
$\mathbf{N}$ \\
-0.648 \\
\end{tabular}} & \multirow{2}{*}{\begin{tabular}{|c|}
$\mathbf{P}$ \\
-0.386
\end{tabular}} & \multirow{2}{*}{\begin{tabular}{|c|}
$\mathbf{F e}$ \\
0.588
\end{tabular}} & \multirow{2}{*}{\begin{tabular}{|c|} 
Mn \\
0.586 \\
\end{tabular}} & \multirow{2}{*}{\begin{tabular}{|c|} 
DO \\
-0.561
\end{tabular}} & \multirow{2}{*}{\begin{tabular}{|l|} 
BOD \\
0.482 \\
\end{tabular}} & \multirow{2}{*}{\begin{tabular}{|c|} 
CO \\
D \\
- \\
0.31 \\
5 \\
\end{tabular}} & \multirow{2}{*}{\begin{tabular}{|l|} 
FCC \\
-0.459 \\
\end{tabular}} & \multirow{2}{*}{\begin{tabular}{|l} 
TBC \\
0.312
\end{tabular}} \\
\hline & $r$ & & & & & & & & & & & & & & & & \\
\hline & $\begin{array}{c}P \\
\text { valu } \\
e\end{array}$ & & 0.002 & 0.0001 & 0.0001 & 0.057 & 0.127 & 0.869 & $\begin{array}{c}0.000 \\
1\end{array}$ & 0.020 & $\begin{array}{c}0.000 \\
1\end{array}$ & $\begin{array}{c}0.000 \\
1\end{array}$ & $\begin{array}{c}0.000 \\
1\end{array}$ & 0.003 & $\begin{array}{c}0.06 \\
1\end{array}$ & 0.005 & 0.064 \\
\hline \multirow[b]{2}{*}{ pH } & $r$ & 0.499 & & 0.045 & 0.433 & 0.206 & 0.180 & 0.109 & -0.801 & -0.658 & -0.221 & -0.191 & 0.172 & 0.419 & $\begin{array}{c}0.11 \\
7\end{array}$ & -0.084 & -0.261 \\
\hline & $\begin{array}{c}P \\
\text { valu } \\
e\end{array}$ & 0.002 & & 0.793 & 0.008 & 0.227 & 0.293 & 0.525 & $\begin{array}{c}0.000 \\
1\end{array}$ & $\begin{array}{c}0.000 \\
1\end{array}$ & 0.196 & 0.265 & 0.317 & 0.011 & $\begin{array}{c}0.49 \\
7\end{array}$ & 0.628 & 0.125 \\
\hline \multirow{2}{*}{$\begin{array}{c}\text { Turbidit } \\
\mathbf{y}\end{array}$} & $r$ & 0.617 & 0.045 & & 0.630 & 0.449 & 0.417 & 0.201 & -0.156 & -0.093 & 0.689 & 0.774 & -0.435 & 0.365 & $\begin{array}{c}0.19 \\
9\end{array}$ & 0.485 & 0.261 \\
\hline & $\begin{array}{c}P \\
\text { valu } \\
e\end{array}$ & $\begin{array}{c}0.000 \\
1\end{array}$ & 0.793 & & 0.0001 & 0.006 & 0.011 & 0.240 & 0.363 & 0.589 & $\begin{array}{c}0.000 \\
1\end{array} \mid$ & $\begin{array}{c}0.000 \\
1\end{array}$ & 0.008 & 0.029 & $\begin{array}{c}0.24 \\
4\end{array}$ & 0.003 & 0.124 \\
\hline \multirow[b]{2}{*}{$\begin{array}{l}\text { Hardnes } \\
\quad \mathrm{s}\end{array}$} & $r$ & 0.672 & 0.433 & 0.630 & & 0.811 & 0.726 & 0.498 & -0.357 & -0.183 & 0.291 & 0.458 & -0.217 & 0.775 & $\begin{array}{c}0.11 \\
6\end{array}$ & 0.112 & -0.097 \\
\hline & \begin{tabular}{|c}
$P$ \\
valu \\
$e$
\end{tabular} & $\begin{array}{c}0.000 \\
1\end{array}$ & 0.008 & 0.0001 & & $\begin{array}{c}0.000 \\
1\end{array}$ & $\begin{array}{c}0.000 \\
1\end{array}$ & 0.002 & 0.032 & 0.287 & 0.085 & 0.005 & 0.204 & $\begin{array}{c}0.000 \\
1\end{array}$ & $\begin{array}{c}0.50 \\
0\end{array}$ & 0.517 & 0.575 \\
\hline \multirow[b]{2}{*}{ TS } & $r$ & 0.320 & 0.206 & 0.449 & 0.811 & & 0.910 & 0.723 & 0.054 & 0.169 & 0.094 & 0.349 & 0.063 & 0.822 & $\begin{array}{c}0.52 \\
2\end{array}$ & 0.000 & -0.019 \\
\hline & \begin{tabular}{|c|}
$P$ \\
valu \\
$e$
\end{tabular} & 0.057 & 0.227 & 0.006 & 0.0001 & & $\begin{array}{c}0.000 \\
1\end{array}$ & $\begin{array}{c}0.000 \\
1\end{array}$ & 0.755 & 0.323 & 0.586 & 0.037 & 0.716 & $\begin{array}{c}0.000 \\
1\end{array}$ & $\begin{array}{c}0.00 \\
1\end{array}$ & 0.999 & 0.912 \\
\hline \multirow[b]{2}{*}{ CL } & $r$ & 0.259 & 0.180 & 0.417 & 0.726 & 0.910 & & 0.615 & 0.049 & 0.156 & 0.123 & 0.360 & 0.093 & 0.692 & $\begin{array}{c}0.51 \\
8\end{array}$ & 0.112 & 0.048 \\
\hline & \begin{tabular}{|c|}
$P$ \\
valu \\
$e$ \\
\end{tabular} & 0.127 & 0.293 & 0.011 & 0.0001 & $\begin{array}{c}0.000 \\
1\end{array}$ & & $\begin{array}{c}0.000 \\
1\end{array}$ & 0.776 & 0.365 & 0.474 & 0.031 & 0.590 & $\begin{array}{c}0.000 \\
1\end{array}$ & $\begin{array}{c}0.00 \\
1\end{array}$ & 0.515 & 0.781 \\
\hline \multirow[b]{2}{*}{$\mathrm{Na}$} & $r$ & 0.029 & 0.109 & 0.201 & 0.498 & 0.723 & 0.615 & & 0.105 & 0.050 & -0.110 & 0.051 & 0.197 & 0.584 & $\begin{array}{c}0.52 \\
7\end{array}$ & -0.077 & -0.097 \\
\hline & \begin{tabular}{|c|}
$P$ \\
valu \\
$e$ \\
\end{tabular} & 0.869 & 0.525 & 0.240 & 0.002 & $\begin{array}{c}0.000 \\
1\end{array}$ & $\begin{array}{c}0.000 \\
1\end{array}$ & & 0.542 & 0.774 & 0.521 & 0.768 & 0.250 & $\begin{array}{c}0.000 \\
1\end{array}$ & $\begin{array}{c}0.00 \\
1\end{array}$ & 0.657 & 0.574 \\
\hline \multirow[b]{2}{*}{18} & $r$ & -0.648 & -0.801 & -0.156 & -0.357 & 0.054 & 0.049 & 0.105 & & 0.873 & -0.065 & 0.013 & 0.137 & -0.202 & \begin{tabular}{|c}
0.18 \\
3 \\
\end{tabular} & -0.142 & 0.096 \\
\hline & \begin{tabular}{|c|}
$P$ \\
valu \\
$e$
\end{tabular} & $\begin{array}{c}0.000 \\
1\end{array}$ & $\begin{array}{c}0.000 \\
1\end{array}$ & 0.363 & 0.032 & 0.755 & $0.77+$ & 0.542 & & $\begin{array}{c}0.000 \\
1\end{array}$ & 0.707 & 0.941 & 0.425 & 0.238 & $\begin{array}{c}0.28 \\
5\end{array}$ & 0.408 & 0.578 \\
\hline & $r$ & -0.386 & -0.658 & -0.093 & -0.183 & 0.169 & 0.156 & 0.050 & 0.873 & & 0.029 & 0.151 & -0.020 & -0.079 & $\begin{array}{c}0.12 \\
6\end{array}$ & $-0.157 \mid$ & 0.130 \\
\hline & $\begin{array}{c}P \\
\text { valu } \\
e\end{array}$ & 0.020 & $\begin{array}{c}0.000 \\
1\end{array}$ & 0.589 & 0.287 & 0.323 & 0.365 & 0.774 & $\begin{array}{c}0.000 \\
1\end{array}$ & & 0.867 & 0.381 & 0.906 & 0.648 & $\begin{array}{c}0.46 \\
2\end{array}$ & 0.361 & 0.450 \\
\hline
\end{tabular}


Citation: Mokhtar S. El-Beheary et al., 2019. Water Quality and Monitoring of Some Pollution Indicators in Lake Manzala, Egypt. Advances in Environmental Biology., 13(12): 21-29. DOI:10.22587/aeb.2019.13.12.5

\begin{tabular}{|c|c|c|c|c|c|c|c|c|c|c|c|c|c|c|c|c|c|}
\hline \multirow{2}{*}{$\mathrm{Fe}$} & $r$ & 0.588 & -0.221 & 0.689 & 0.291 & 0.094 & 0.123 & -0.110 & -0.065 & 0.029 & & 0.784 & -0.796 & 0.025 & $\begin{array}{c}- \\
0.34 \\
5\end{array}$ & 0.766 & 0.597 \\
\hline & $\begin{array}{c}P \\
\text { valu } \\
e\end{array}$ & $\begin{array}{c}0.000 \\
1\end{array}$ & 0.196 & 0.0001 & 0.085 & 0.586 & 0.474 & 0.521 & 0.707 & 0.867 & & $\begin{array}{c}0.000 \\
1\end{array}$ & $\begin{array}{c}0.000 \\
1\end{array}$ & 0.883 & $\begin{array}{c}0.03 \\
9\end{array}$ & $\begin{array}{c}0.000 \\
1\end{array}$ & $\begin{array}{c}0.000 \\
1\end{array}$ \\
\hline \multirow{2}{*}{ Mn } & $r$ & 0.586 & -0.191 & 0.774 & 0.458 & 0.349 & 0.360 & 0.051 & 0.013 & 0.151 & 0.784 & & -0.650 & 0.227 & $\begin{array}{c}- \\
0.17 \\
5\end{array}$ & 0.652 & 0.590 \\
\hline & $\begin{array}{c}P \\
\text { valu } \\
e\end{array}$ & $\begin{array}{c}0.000 \\
1\end{array}$ & 0.265 & 0.0001 & 0.005 & 0.037 & 0.031 & 0.768 & 0.941 & 0.381 & $\begin{array}{c}0.000 \\
1\end{array}$ & & $\begin{array}{c}0.000 \\
1\end{array}$ & 0.184 & $\begin{array}{c}0.30 \\
7\end{array}$ & $\begin{array}{c}0.000 \\
1\end{array}$ & $\begin{array}{c}0.000 \\
1\end{array}$ \\
\hline \multirow[b]{2}{*}{ DO } & $r$ & -0.561 & 0.172 & -0.435 & -0.217 & 0.063 & 0.093 & 0.197 & 0.137 & -0.020 & -0.796 & -0.650 & & 0.022 & $\begin{array}{c}0.52 \\
5\end{array}$ & -0.558 & -0.467 \\
\hline & $\begin{array}{c}P \\
\text { valu } \\
e\end{array}$ & $\begin{array}{c}0.000 \\
1\end{array}$ & 0.317 & 0.008 & 0.204 & 0.716 & 0.590 & 0.250 & 0.425 & 0.906 & $\begin{array}{c}0.000 \\
1\end{array}$ & $\begin{array}{c}0.000 \\
1\end{array}$ & & 0.897 & $\begin{array}{c}0.00 \\
1\end{array}$ & $\begin{array}{c}0.000 \\
1\end{array}$ & 0.004 \\
\hline \multirow[b]{2}{*}{ BOD } & $r$ & 0.482 & 0.419 & 0.365 & 0.775 & 0.822 & 0.692 & 0.584 & -0.202 & -0.079 & 0.025 & 0.227 & 0.022 & & $\begin{array}{c}0.30 \\
5\end{array}$ & -0.043 & -0.120 \\
\hline & $\begin{array}{c}P \\
\text { valu } \\
e \\
\end{array}$ & 0.003 & 0.011 & 0.029 & 0.0001 & $\begin{array}{c}0.000 \\
1\end{array}$ & $\begin{array}{c}0.000 \\
1\end{array}$ & $\begin{array}{c}0.000 \\
1\end{array}$ & 0.238 & 0.648 & 0.883 & 0.184 & 0.897 & & $\begin{array}{c}0.07 \\
0\end{array}$ & 0.804 & 0.486 \\
\hline \multirow[b]{2}{*}{ COD } & $r$ & -0.315 & 0.117 & -0.199 & 0.116 & 0.522 & 0.518 & 0.527 & 0.183 & 0.126 & -0.345 & -0.175 & 0.525 & 0.305 & & -0.127 & -0.403 \\
\hline & $\begin{array}{c}P \\
\text { valu } \\
e\end{array}$ & 0.061 & 0.497 & 0.244 & 0.500 & 0.001 & 0.001 & 0.001 & 0.285 & 0.462 & 0.039 & 0.307 & 0.001 & 0.070 & & 0.462 & 0.802 \\
\hline \multirow{2}{*}{ FCC } & $r$ & 0.459 & -0.084 & 0.485 & 0.112 & 0.000 & 0.112 & -0.077 & -0.142 & -0.157 & 0.766 & 0.652 & -0.558 & -0.043 & $\begin{array}{c}- \\
0.12 \\
7\end{array}$ & & 0.761 \\
\hline & $\begin{array}{c}P \\
\text { valu } \\
e \\
\end{array}$ & 0.005 & 0.628 & 0.003 & 0.517 & 0.999 & 0.515 & 0.657 & 0.408 & 0.361 & $\begin{array}{c}0.000 \\
1\end{array}$ & $\begin{array}{c}0.000 \\
1\end{array}$ & $\begin{array}{c}0.000 \\
1\end{array}$ & 0.804 & $\begin{array}{c}0.46 \\
2\end{array}$ & & $\begin{array}{c}0.000 \\
1\end{array}$ \\
\hline \multirow{2}{*}{ TBC } & $r$ & 0.312 & -0.261 & 0.261 & -0.097 & -0.019 & 0.048 & -0.097 & 0.096 & 0.130 & 0.597 & 0.590 & -0.467 & -0.120 & \begin{tabular}{|c|}
- \\
0.04 \\
3 \\
\end{tabular} & 0.761 & \\
\hline & $\begin{array}{c}P \\
\text { valu } \\
\boldsymbol{e}\end{array}$ & 0.064 & 0.125 & 0.124 & 0.575 & 0.912 & 0.781 & 0.574 & 0.578 & 0.450 & $\begin{array}{c}0.000 \\
1\end{array}$ & $\begin{array}{c}0.000 \\
1\end{array}$ & 0.004 & 0.486 & $\begin{array}{c}0.80 \\
2\end{array}$ & $\begin{array}{c}0.000 \\
1\end{array}$ & \\
\hline
\end{tabular}

$r=$ Pearson bivariate correlation co-efficient; $\mathrm{T}=$ temperature; $\mathrm{TS}=$ Total solids; $\mathrm{CL}=$ chloride ion; $\mathrm{Na}=\mathrm{sodium}$ ion; $\mathrm{N}=\mathrm{Nitrogen}$ ion; $\mathrm{P}=$ phosphorus ion; $\mathrm{Fe}=\mathrm{Iron} ; \mathrm{Mn}=$ Manganese; $\mathrm{DO}=$ Dissolved oxygen; $\mathrm{BOD}=\mathrm{Biological}$ oxygen demand; $\mathrm{COD}=$ Chemical oxygen demand; $\mathrm{FCC}=$ Faecal coliform count and $\mathrm{TBC}=$ Total Bacterial count. $P$ value $<0.05$ is considered statistically significant.

\section{REFERENCE}

[1] Beheary, M. S., et al., 2018. Environmental risk assessment of heavy metals contamination in industrial drain connected to Mediterranean Sea. Advances in Environmental Biology.12 (11): 1-13.DOI:10.22587/aeb.2018.12.11.1.

[2] Yi, Y. J.; Wang, Z. Y, Zhang, K. and Yu. G. A., 2008. Sediment pollution and its effect on fish through food chain in the Yangtze River. Int. J. Sediment Res., 23: 338-347.

[3] Rasmussen, E. K., Petersen, O. S., Thompson, J. R., Flower, R. J., and Ahmed, M. H., 2009. Hydrodynamic ecological model analyses of the water quality of Lake Manzala (Nile Delta, Northern Egypt). Hydrobiology 622, $195-220$.

[4] General Authority for Fishery Resources Development (GAFRD), Yearbook of Fishery Statistics in Egypt (2003-2012), Cairo, Egypt (2014).

[5] Montasir, A. H., 1937. On the ecology of Lake Manzala. Bull. Fac. Sci. Egypt. Univ. Cairo, 12: 50.

[6] Shehata, S. M. A., 1982. Comparative study on the feeding habits, food items, and functional anatomy of the alimentary tract of some fishes native to Lake Manzalah. Ph. D. Thesis, Zool. Dep., Fac. of Sci., Al-Azhar Univ. Egypt.303 pp.

[7] El-Enany, H. R., 2004. Ecological and biological studies on Lake El-Manzalah with special reference to their water quality and sediment productivity. M. Sc. Thesis, Fac. Sci., Al Azhar Univ.

[8] Zahran, M.A., El-Amier, Y.A., Elnaggar, A.A., Abd El-Azim, H. and El-Alfy, M.A., 2015. Assessment and Distribution of Heavy Metals Pollutants in Manzala Lake, Egypt. Journal of Geoscience and Environment Protection, 3,107-122.

[9] Serag, M. S. 2015. Bahr El Baqar Drain: Ecological and Historical Studies: Negative affects human health and Lake Manzala. P40. In Arabic.

[10]Elshemy, M., 2016. Water Quality Assessment of Lake Manzala, Egypt: A Comparative Study. International Journal of Scientific Research in Environmental Sciences. 4. 196-207. 10.12983/ijsres-2016-p0196-0207. 
[11]Environmental Protection Agency (EPA), Parameters of water quality, Interpretation and Standards, Wexford, Ireland (2001)

[12]El-Refaie, G., 2010. 'Temperature impact on operation and performance of Lake Manzala Engineered Wetland, Egypt', Ain Shams Engineering Journal, 1(1), pp. 1-9.

[13]Fathi, A.A., and Abdelzaher, H.M., 2003. Limnological studies on wetland Lake El-Manzalah, Egypt.Bull.Fac.Sci, Assiut Univ., $215-233$.

[14] Ahmed, M. A., Aly, A. I. M., and Hussien, R. A., 2013. Human-induced and eutrophication impacts on physiochemical and isotopic water characteristics of a northeastern Nile Delta Lake, Egypt. Arab Journal of Nuclear Science and Applications, 46(1): (1-17).

[15] Ali, M., Salam, A., Iram, S., Bokhari, T. Z. and Qureshi, K. A., 2005. Studies on monthly variations in biological and physico-chemical parameters of brackish water fish Pond, muzaffar garh, Pakistan. Journal of Research (Science), 16(1), 27-38.

[16] Khalil, M. T., 1990. The physical and chemical environment of Lake Manzalah, Egypt. Hydrobiol, 196: 193-199.

[17]Zyadah, M., 1995. Environmental impact assessment of pollution in Lake Manzalah and its effect on fishes. Ph. D. Thesis, Fac. Sci., Mansoura Univ. Egypt. 127pp.

[18]El-Enany, H. R., 2004. Ecological and biological studies on Lake El-Manzalah with special reference to their water quality and sediment productivity. M. Sc. Thesis, Fac. Sci., Al Azhar Univ.

[19]El-Kafrawy, S. B., 2004. Monitoring of pollutants in marine environment using remote sensing and GIS system. M. Sc. Thesis, Fac. of Sci., Al-Azhar Univ., Egypt, 216 pp.

[20] Abdel-Satar, A. M., and Geneid, Y. A., 2009. Evaluation of heavy metal status in Ecosystem of lake Manzalah, Egypt. J. Environ. Res., 3(3): 194-204.

[21]El- Alfy, M. A., 2011. An integrated approach for monitoring the impact of industrial activities on the northeastern part of Manzala lagoon, Egypt. M.Sc. Thesis, Environ. Sci. Dep., Damietta Fac. of Sci., Mansoura Univ., Mansoura, Egypt.

[22] Ali, M. M. H., 2008. Assessment of some water quality characteristics and determination of some heavy metals in lake Manzalah, Egypt. Egypt. J. Aquat. Biol. \& Fish., 12(2):133-154.

[23] Berg, H.; Kiibus, M. and Kautsky, N., 1995. Heavy Metals in Tropical Lake Kariba, Zimbabwe. Wat., Air, \& Soil Poll., 83 (3/4): 237-252.

[24] Ibrahim, A. M., M. H. Bahnasawy, S. E. Mansy and R. I. El-Fayomy 1999, Heavy metal accumulation in water, sediment and some fishes in Lake Manzala, Egypt, J. Egypt. Ger. Soc. Zool. 29: 43-58.

[25] Gad, N.S., 2005. Impact of Environmental Pollution in the Southern Region of Lake Manzalah Egypt on Some Biochemical Parameters of Tilapia zillii. J. Egypt. German Soc. Zool., 48, 279.

[26] Giannoulis, N., V. Maipa, I. Konstantinou, T. Albanis and I. Dimoliatis,, 2005. Microbiological risk assessment of Agios Georgios source supplies in northwestern Greece based on faecal coliform determination and sanitary inspection survey. Chemosphere, 58: 1269-1276.

[27] Younis, A. and Nafea, E., 2012. Impact of Environmental Conditions on the Biodiversity of Mediterranean Sea Lagoon, Burullus Protected Area, Egypt. World Appl. Sci. J., 19, 1423-1430.

[28] Fernandes C. F., G. J. Flick, J. L. Silva, and T. A. McCasky., 1997. Influence of processing schemes on indicative bacteria and quality of fresh aquacultured catfish fillets. Journal of Food Protection 60:54-58.

[29] Al-Harbi, A. H., 2003. Faecal coliforms in pond water, sediments and hybrid tilapia Oreochromis niloticus $\times$ Oreochromis aureus in Saudi Arabia. Aquaculture Research, 34:517-524. 